\title{
The Impacts of STEM Instruction on Strengthening High School Students' Reasoning Skills
}

\author{
Uswatun Hasanah* \\ Department of Educational Development and Cultural and Regional Studies, Graduate School for International Development and Cooperation, \\ Hiroshima University, Hiroshima, Japan
}

*Corresponding Author: uswatunhasanah216@yahoo.com

\section{ABSTRACT}

This study aimed to examine the impact of Science, Technology, Engineering, and Mathematics (STEM) instruction on strengthening the reasoning skills of Indonesian high school students. The 63 participants from senior high school were divided into two groups: STEM group and Traditional group. The STEM group received STEM instruction with an emphasis on the four STEM subjects. Instruction used inquiry-based learning to facilitate instruction and to expand the connection between the science learning process with technology, engineering, and mathematics. Students in the STEM group were divided into small groups each consisting of 5-6 students with the teacher functioning as a facilitator to help the students in the learning processes. The traditional group received conventional instruction through reading, listening, and discussion. These two groups were taught by the same teacher and learned the same topic. Twenty-four two-tier multiple-choice questions from Lawson's classroom test of scientific reasoning were utilized to assess students' reasoning skills. In conclusion, a statistically significant difference in students' reasoning skills between the STEM group and traditional group was found. Recommendations are offered to maximize STEM instruction and reasoning skills' measurement in future research.

KEY WORDS: science, technology, engineering, and mathematics; instruction; reasoning skills

\section{INTRODUCTION}

$\mathbf{R}$ easoning skills are characterized as the inquiry processes of students to reexamine and reproduce their hypothesis about the world involved in experimentation, assessment, and induction, deriving logical understanding therefrom. It is the basis for students' procurement of logical information concurring with the strategies they utilize to find, survey, reexamine, and communicate that information (Andersen and Garcia-Mila, 2017). Reasoning skills emerge as a mental process that includes operating and applying knowledge to solve problems, make decisions, achieve goals, and as a complex construct that have been regarded as critical points in science education. They can create a reasoning pattern in youth and play a basic part in developing the capacity to study science and to build scientific concepts (Lawson et al., 2007).

Nowadays, researchers increasingly emphasize the importance of reasoning skills in science (Opitz et al., 2017). In Indonesia, one of the science education's goals is developing students' reasoning skills through utilizing the student's ideas and science material. The Ministry of Education and Cultural (MoEC) highlights the priority in strengthening the students' achievement, academic skills, and the $21^{\text {st }}$ century skills in science, technology, and mathematics (MoEC, 2016). The Indonesian government has emphasized the importance of skills development to economic growth. It should be noted that in Indonesia, the skills system is regulated by various legal decisions: Law 20/2003 on the Education System; Law 12/2003 on Labor and Manpower;
Presidential Regulation 8/2012 on the Indonesian National Qualification Framework; Presidential Regulation 9/2016 on Revitalization of secondary vocational schools (SMKs); Government Regulation 31/2006 on National Training System; and the Government Regulation 10/2018 on the Indonesian Professional Certification Authority (The World Bank, 2019).

Even though the Indonesian government has employed fiscal effort, it has been noted that certain issues still arise during curriculum development. In fact, students currently still demonstrate difficulties in reasoning application. These difficulties are caused by insufficient learning strategy, resulting in the level of reasoning that is still low, straight, and disintegrated (Suhandi and Nugraha, 2017). Marusic and Slisko (2012) confirmed that reasoning skills would not be achieved through substantial knowledge in a traditional format. Developing concrete reasoning skills can be achieved by crossdomain strategies such as science, technology, engineering, and mathematic (STEM) instruction (Kuhn et al., 1992; Sanders, 2009). The learning process should encourage students to find various sources of observation and be able to communicate problems. They need to consider the knowledge systematically and acquire the competence to collaborate in solving the problem (Suhandi and Nugraha, 2017).

Therefore, Indonesian government is now adapting STEM instruction to the current curriculum (Fransisca et al., 2019). STEM instruction is believed to contribute to science curriculum, especially in developing the students' knowledge, affective, and 
skills dimension (Kanadli, 2019). STEM is considered to be an effective element for the learning process not only to create higher achievement scores but also to improve conceptual understanding and $21^{\text {st }}$ century skills (Angwal et al., 2019; Huri and Karpudewan, 2019; Sari et al., 2017). These studies have shown the benefits of STEM instruction and the positive effect of STEM in strengthening students' skills. Nevertheless, none of these evidence-based studies have confirmed how STEM instruction impacts on reasoning skills as one of the crucial points in science education in Indonesia. This paper's researcher recognized the need for a comprehensive study focused on Indonesia. Hence, this study aimed to determine the effects of STEM instruction on secondary school students' reasoning skills. For this purpose, the following research questions were framed:

1. Is there any statistically significant difference in the students' reasoning skills between STEM group and traditional group?

2. How effective is STEM instruction in improving reasoning skills of Indonesian students comparing to traditional instruction?

\section{LITERATURE REVIEW}

\section{STEM Instruction}

In the 1990s, The National Science Foundation (NSF) started using the acronym "SMET" standing for "Science, Mathematics, Engineering, and Technology" and then it changed to the new term, STEM, in 2001. In the past two decades, NSF has used STEM to refer to the four separate and distinct fields. In the fall of 2007, they realized that the acronym of STEM is ambiguities; thus, STEM education was retitled and become "Integrative STEM Education." The notion of integrative STEM education includes approaches to explore teaching and learning between and among any two or more of STEM subject, and between a STEM subject (Sanders, 2009). The specializations of each subject are explained as follows (Burghardt and Hacker, 2004; Kelley and Knowles, 2016; National Research Council, 2014):

1. Scientific inquiry. Science is the study of the natural world, including the laws of nature associated with the subjects and the treatment or application of facts, principles, concepts, or conventions associated with the disciplines. Science is preparing students to think and act like real scientists, ask questions, hypothesize, and conduct investigations using standard science practices

- Science concepts: Life sciences, physical sciences, and chemical sciences

2. Technology. As objects, knowledge, activities, and volition

- Technology concepts: Technology as tools, technology as ideas, and technology as product of science;

3. Engineering design. As an approach to delivering STEM education creates an ideal entry point to include engineering practices into existing secondary curriculum

- Engineering design concepts: Models, designs, problem-solving, communicating ideas, planning, and implementing
4. Mathematics thinking. Providing the necessary rationale for students to learn mathematics through valuating design solutions and see the connections between what should be learned in school with what is required in STEM career skills

- Mathematical concepts: Numbers, problem-solving, geometry, measurement, representation of math ideas using objects, symbols, and words.

STEM education is where the academic concepts are coupled with real-world lessons in contexts that make connections among school, community, work, and the global enterprise (Akaygun and Aslan-Tukak, 2016; Cevik and Ozgunay, 2018; Tsupros et al., 2009). Moore et al. (2014) designated a framework that includes six principles for STEM education including the inclusion of math and science content, studentcentered pedagogy, the means of making mistakes, group collaboration, engaging and motivating lesson, and integration of engineering design of redesign challenge.

STEM provides benefits for the student through giving opportunities to integrate multidisciplinary research topics in their studies (Jacobs and Eccles, 2000; National Research Council, 2014). Further, it also comes up as a key to achieve critical competencies such as problem-solving skills, social communication skills, technology and engineering skills, and system skills (Jang, 2016). STEM is an unfolding of learning, which supports student' explorations, questions, conversations, and reveals how competent the students are in STEM subject (DeCoito et al., 2016). STEM education is believed to contribute to the development of $21^{\text {st }}$ century skills (Altan et al., 2018).

In conclusion, the definition of STEM depends on the contextual factor, such as the roles of stakeholders in implementing STEM education most definitions are possible (Radloff and Guzey, 2016). Due to the ambiguous understanding, various frameworks were used to define the integration of STEM (Asunda, 2014; English, 2016).

Therefore, in this study, STEM is defined as a multidisciplinary instruction to learn science through the mixture of the acts of scientific inquiry, technology and engineering design, arithmetical study, and $21^{\text {st }}$ century skills. In STEM instruction, the academic concepts are combined with the context in realworld activity, connecting the schools, society, employment, and global enterprise (Sallee et al., 2013). The development of STEM affords the opportunity of every single student to improve abilities fundamental for $21^{\text {st }}$ century learning, and by utilizing an assortment of movement-based learning models, students are given chances to get more useful information (Meyrick, 2011; Shernoff et al., 2017).

STEM instruction is an authentic instruction, as per Piaget (1969) and Vygotsky (1978). In authentic instruction, higher-order thinking is the foundation for student learning. This instruction is designed to ensure that students have the opportunity to rethink, postulate, analyze, and evaluate 
information to develop new and practical meaning. Instruction facilitates students' depth of knowledge, using the content of knowledge to solve the problem and construct knowledge. It connects learning, processes, and problems to the real world in a way that learners can relate to (Blue, 2014). STEM instruction positively influences the performance of the average student. The goals of STEM instruction are to foster higher-order thinking skills such as metacognitive thinking, asking, and using probing questioning, reasoning, challenging students to question the "status quo" and provide writing prompts to encourage analysis (Preus, 2012). It facilitates students' depth of knowledge using the content of knowledge to solve the problem and construct knowledge.

STEM instruction advances more understanding of the nature of science, innovation, designing, through genuine contexts (Akerson et al., 2018; Means et al., 2017). The California STEM Learning Network (2012) stated "STEM is more than just individual disciplines and indicates an interdisciplinary and applied approach to teaching these subjects. STEM instruction displaces the conventional barriers erected between the four disciplines by integrating them into one cohesive teaching and learning paradigm" (Wasserman and Rossi, 2015. p. 23). STEM instruction has considerable effects on the students' choices toward a STEM career. It can make meaningful learning possible, develop important careers content standards, and useful skills in everyday life.

STEM is centered on collaborative education, problem-based learning, and inquiry-based learning throughout the subjects (Chiu et al., 2015). Research confirms that the better STEM courses and curricula should reflect the following features:

1. Adopting student's outcomes, reflecting the most updated material, and understanding in STEM education

2. Providing chances to connect STEM teachers and their students with the wider society and workforce

3. Contributing students interdisciplinary, multinational, and multi-point of evaluations to illustrate how STEM exceeds national boundaries in providing students a global viewpoint

4. Covering mathematics and science teaching and curriculum

5. Integrating, at least, technology and engineering into the science and mathematics curriculum

6. Applying appropriate innovations such as demonstrating, regeneration, and separation figuring out how to improve STEM learning encounters and examinations;

7. Being available within formal and informal learning experiences

8. Offering an applicable context for learning and core content knowledge of integrated STEM throughout approaches

9. Encouraging engineering design and problem-solving (scientific/engineering) - the process of identifying a problem, solution innovation, prototype, evaluation, and redesign - as a way to develop a practical understanding of the designed world
10. Promoting inquiry - the process of asking questions and conducting investigations - as a way to develop a deep understanding of nature and designed world

11. Being completed with proper resources and covering minds-on, hands-on, and community-oriented ways to process the learning (National Sciecne Teacher Assocation, 2004).

Moore et al. (2014) described five characteristics that differentiates STEM from other forms of instruction: (a) The materials and interests in science and mathematics characterize a quantity of significant objectives in the learning process; (b) the engineering practices and engineering design of innovations become the integrator and also the specific context in STEM; (c) science and scientific ideas are utilized through design encouragement; (d) the improvement of $21^{\text {st }}$ century skills is highlighted; and (e) the setting of guidance needs taking care of a real issue or undertaking through cooperation. These characteristics have potential to encourage more overwhelming levels of higher-order thinking and problem-solving in students around the world (Schnittka, 2017).

\section{Reasoning Skills}

Reasoning skills are the process of arranging principles and evidence to generate new conclusions (Lee and She, 2010). Reasoning includes the intellectual skills of inquiry, evidence, experimentation, inference, evaluation, and argumentation (Zimmerman, 2005). Based on Alshamali and Daher (2016), reasoning skills are considered significant in facilitating science learning. It includes a broad scope of scientific and engineering aspects in evidence-based learning cases and arrangements such as posing queries and characterizing problems, creating and utilizing models, arranging and doing investigations, analyzing and clarifying data, developing clarifications, taking part in experimental hypothesis, and acquiring, assessing, and conveying data. These are necessary to equip people for addressing everyday life and social responsibility, besides tackling socioscientific issues confronting the general public (Osborne, 2013).

Reasoning skills are related to fundamental inferences that help students to organize indication and theoretical hypothesis (Kuhn and Dean, 2004). Alshamali and Daher (2016) explained that processes that encouraged the use of reasoning skills include: Urging students to look for scientific data beyond their textbooks; concentrating on scientific thinking and problem solving skills; making tracks in an opposite direction from indoctrination; expecting students to clearly clarify and bring up logical inquiries and issues; considering quality instead of amount in the educating/learning process; utilizing various techniques to instruct science certainties; and starting from students' experiences to rise their active role in the development of reasoning skills.

A few procedures block the advancement of reasoning skills. These include: Intolerance of teachers toward students' different suppositions; pre-conception of parents and teachers toward students' inquiry by overlooking them and furnishing 
inadequate responses; limits placed on students' capacity to think; conventional test items arranged to inspire a solitary correct answer; students given the thoughts, perceptions, and arrangements they could develop themselves; students not supported in basic reasoning; and the manner in which students are taught in schools and colleges, which makes them forsake or overlook the scientific speculation approach in their instruction. These should be avoided in the learning process.

In this study, reasoning skills focused on six domains including: (1) Conservation laws (CMV); (2) proportional thinking (PPT); (3) control of variables (CV); (4) probabilistic thinking; (5) correlational thinking (CT); and (6) hypothetical-deductive reasoning (HDR) (Lawson, 2000).

1. Conservation laws skill consists of two subskills: Conservation of weight and conservation of volume. This skill is a fundamental reasoning skill and requires the students to conclude simple explanations about one concept

2. PPT skill is the application of the given information and the ability to connect and discover one broad variable

3. CV skill is the procedure in controlling dependent and independent variables.

4. Probabilistic reasoning skill is a powerful and a specific procedure that delivers a specific outcome when revised the identical conditions

5. CT skills is utilized to conclude the strength of the common relationship between variables

6. HDR skill is the character of the reasoning process, which produces increasing and establishing potential keys for dealing with the issue.

These skills symbolize various practices that are commonly considered as a necessity for efficient science inquiries and cut across many STEM and STEM-related disciplines (Lawson, 2000; National Research Council, 2011; Zimmerman, 2005).

\section{METHODOLOGY}

\section{Participants and Context}

This study was conducted using quasi-experimental design with control and experimental group. The total participants were volunteers that consisted of 63 secondary school students in Grade 10 (students aged 15-16) from one public school in Pangkep, South Sulawesi, Indonesia. Purposive random sampling technique was used to determine this sample. Purposive random sampling is the most effective sampling method when one needs to study a certain cultural domain with a specific skill (Gentles et al., 2015).

The details of the competency in physics education in Indonesia are shown in Table 1. As noted, this competency starts with developing curiosity, then formulating problems, analyzing concepts, and modifying or designing simple project. Each of this competencies are related to the all the content that has been decided by the Ministry of Education.

In this study, the scope of the content covered only "static and dynamic fluid" that was delivered though six meetings that included a pre- and post-test as well as four meetings for each STEM group and traditional group, as shown in Figure 1.

Further, all participants were divided into two groups: The STEM group as the experimental group and the traditional group as the control group. The STEM group received STEM instruction with inquiry-based learning and the connection between the science learning process and technology, engineering, and mathematics (Blue, 2014; Warner and Myers, 2012). There are five general inquiry phases including orientation, conceptualization, investigation, conclusion, and discussion (Pedaste et al., 2015). STEM instruction in this study was divided into four learning processes and the detail is presented in Table 2 .

Students in the STEM group were divided into small groups (each group consists of 5-6 students) and the teacher functioned as a facilitator to help the students in problemsolving during the learning process. Meanwhile, the traditional group received conventional instruction through reading, listening, and discussion related to the concept of "Hydraulic system, hydrostatic pressure, and Pascal's law." The students also learned individually before and after receiving the lectures in the class. These two groups were taught by the same teacher and learned the same topic in each of the four teaching sessions.

\begin{tabular}{|c|c|c|}
\hline Competency level & Competency & The scope of content \\
\hline Senior high school & $\begin{array}{l}\text { - Developing curiosity, honesty, responsibility, logical, critical, analytical, } \\
\text { and creative through learning physics } \\
\text { - Formulating problems related to physical phenomena, formulate } \\
\text { hypotheses, design and carry out experiments, take meticulous } \\
\text { measurements, record and present results in tables and graphs, conclude, } \\
\text { and report results verbally and in writing } \\
\text { - Analyzing the concepts, principles, and laws of mechanics, fluids, } \\
\text { thermodynamics, waves, and optics and applying metacognition in } \\
\text { explaining natural phenomena and solving the problems of life } \\
\text { - Modifying or designing simple projects related to the application of the } \\
\text { concepts of mechanics, fluid, thermodynamics, waves, or optics }\end{array}$ & $\begin{array}{l}\text { - The nature of physics and measurement of physical } \\
\text { quantities } \\
\text { - Kinematics } \\
\text { - Dynamics motion } \\
\text { - Hooke's elasticity and law } \\
\text { - Static and dynamic fluid } \\
\text { - Temperature, heat, symptoms of global warming } \\
\text { (causes, effects, and the solution) } \\
\text { - Wave equation } \\
\text { - Light and optical devices } \\
\text { - Soundwave }\end{array}$ \\
\hline
\end{tabular}




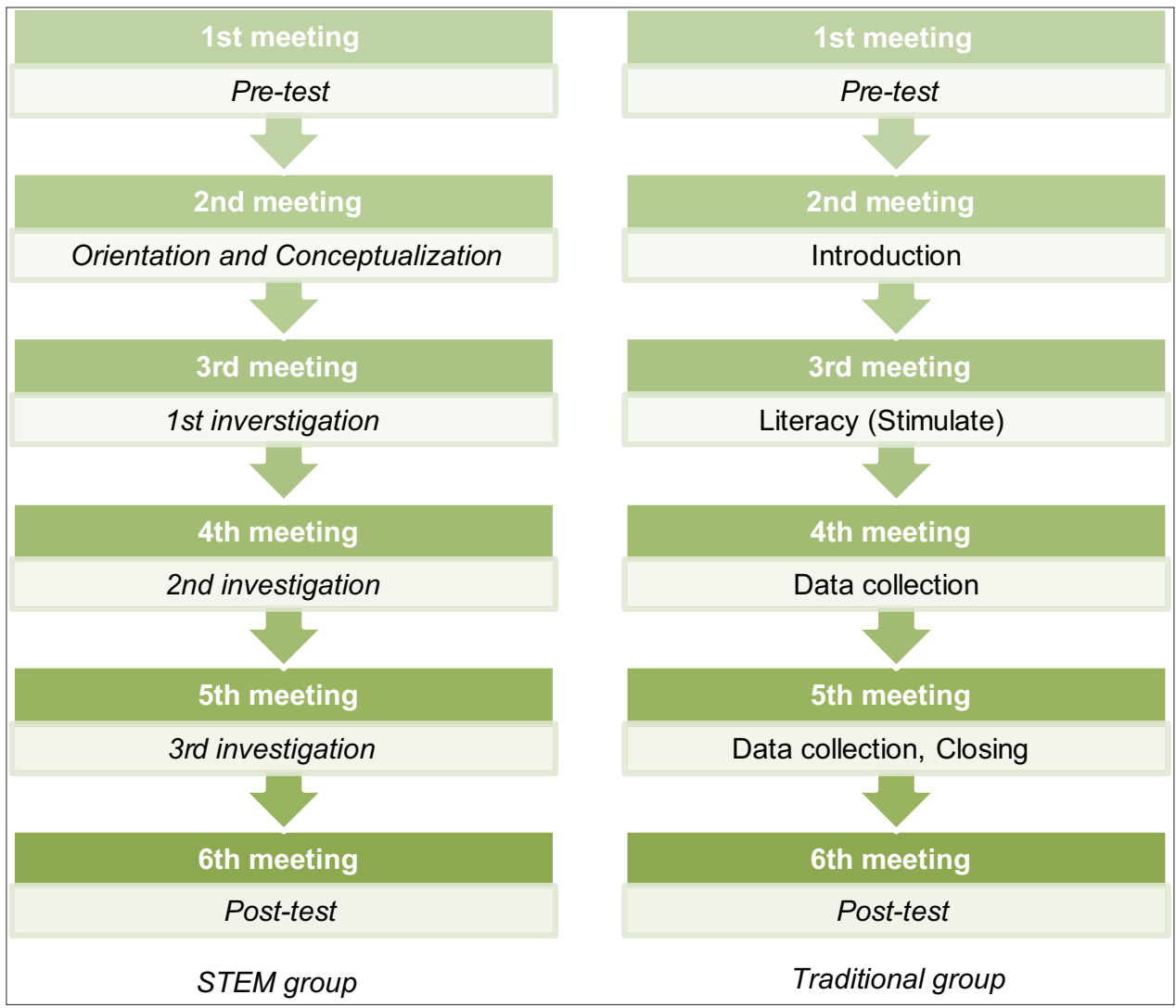

Figure 1: Meeting details

\section{Instrument and Analysis Method}

Many instruments have been used to examine students' reasoning skills, as for example, the scientific reasoning test version 9 and test of scientific literacy skills. These instruments tend to target a broad context such as the nature of science and integrity in sociocultural sets (Gormally et al., 2012; Sundre and Thelk, 2010). Another instrument is the Lawson's classroom test of scientific reasoning (LCTSR) that has been utilized for almost three decades and signifies students' skill development from middle school to university level. It is a task-based evaluation to assemble quantitative data on reasoning skills (Ding et al., 2016; Lawson, 2000; Stammen et al., 2018). In this study, the researcher utilized 24 items of two-tier multiple-choice questions from the LCTSR (Lawson, 1978). The details of the questions for each subskill are listed in Table 3 and a sample is shown in Figure 2.

The items have increasing difficulty. Concerning the evaluation of the test, items 1-22 are counted as the two-tier question and the score assignment assumes that clarifying is more laborious than knowing and providing an incorrect answer with a correct explanation means guessing. The response pattern and score assignment is shown in Table 4. Items 23 and 24 are counted as general multiple-choice questions with 0 or 1 scoring method only. The researcher analyzed the matter further with SPSS program, using analysis covariance and t-test analysis.

\section{RESULTS}

In this study, 56 of 63 students from both groups completed the pre- and post-test using LCTSR. Table 5 shows that the mean score of the control group significantly decreased (4.4074-2.7931) and the mean score of the STEM group slightly increased (3.3871-4.4483).

According to the data presented in Table 6, there was a statistically significant difference between post-test value of the reasoning skills in the traditional group and STEM group $(\rho=.000<0.05)$. These results revealed that STEM instruction appeared to be more effective than traditional instruction in strengthening the reasoning skills of these participating students.

For further analysis in examining the effect of the STEM instruction to each subskill, the data analysis was continued using paired sample $t$ test. Further, the traditional group's result is presented in Table 7 shows a loss of 36\% in the reasoning skills values. Students were left with less knowledge about the skills than they had before. Conservation of weight and volume skills $(\rho=0.631, \rho>0.05)$, proportional reasoning $(\rho=0.161, \rho>0.05)$, and correlation $(\rho=0.070, \rho>0.05)$ showed no significant difference. Moreover, the improvement of mean score and significant differences was found only in probabilistic reasoning skill.

Table 8 presented the t-test result of the students in the STEM group. The mean score of four subskills improved (conservation 


\begin{tabular}{|c|c|}
\hline Meeting & Activity \\
\hline \multirow[t]{2}{*}{$1^{\text {st }}$} & $\begin{array}{l}\text { Orientation and conceptualization (questioning, hypothesis } \\
\text { generation) }\end{array}$ \\
\hline & $\begin{array}{l}\text { Introducing the topic, the theory, the concept of "Hydraulic } \\
\text { system, hydrostatic pressure, Pascal law" as a part of science } \\
\text { domain through pictures and video (showing the example of } \\
\text { hydraulic machine); conducting observation and searching } \\
\text { for information on the web about the topic; raising inquiry } \\
\text { question; setting the hypothesis such as "What should } \\
\text { students do to maximize the function of hydraulic law?"; and } \\
\text { brainstorming for solution }\end{array}$ \\
\hline \multirow[t]{2}{*}{$2^{\text {nd }}$} & $1^{\text {st }}$ Investigation (exploration, experimentation) \\
\hline & $\begin{array}{l}\text { Carrying out the plan about "Hydraulic system" (the body, the } \\
\text { arms, the forearm and the gripper); designing the "Hydraulic } \\
\text { Robot" as a part of engineering domain; listing the equipment } \\
\text { (cardboard for the all parts, syringes as a piston, long tube, } \\
\text { toothpicks/sticks, superglue, and water) and the activities that } \\
\text { students should do to create "Hydraulic Robot;" identifying } \\
\text { resources; conducting observation through all information } \\
\text { sources including book and internet }\end{array}$ \\
\hline \multirow[t]{2}{*}{$3^{\text {rd }}$} & $2^{\text {nd }}$ investigation (experimentation, data interpretation); \\
\hline & $\begin{array}{l}\text { Preparing the equipment; finding the pattern as a part of } \\
\text { mathematics domain (e.g., the concept of the syringes as } \\
\text { a piston and how they manage the fluid inside the piston); } \\
\text { conducting experiment; and reconstructing the "Hydraulic } \\
\text { Robot" }\end{array}$ \\
\hline \multirow[t]{2}{*}{$4^{\text {th }}$} & $\begin{array}{l}3^{\text {rd }} \text { investigation (experimentation, analysis) and discussion } \\
\text { (communication, presentation, reflection); }\end{array}$ \\
\hline & $\begin{array}{l}\text { Finishing the experiment; integrating all information and } \\
\text { students' idea based on the evidence to complete their } \\
\text { "Hydraulic Robot;" creating the explanation for their } \\
\text { "Hydraulic Robot;" presenting the result as a part of } \\
\text { technology domain to get some reflection from the other group }\end{array}$ \\
\hline
\end{tabular}

of weight and volume (0.6897-7586), proportional reasoning (0.0690-0.1034), CV (0.1494-1725), and HDR (0.0690$0.3678)$ ). However, these skills did not produce significant differences in STEM group. Only HDR skill shown statistically significant difference $(\rho=0.000, \rho<0.05)$ and had the highest improvement of mean score comparing to the other subskills.

\section{DISCUSSIONS}

This study aimed to examine the effects of STEM instruction on strengthening reasoning skills of Indonesian high school students using LCTSR. Previous research has constructed several results about the relationship between STEM education and many aspects in science, including knowledge, affective, and skills, as well as the improvement of $21^{\text {st }}$ century skills. Kanadli (2019) and Sari et al. (2017) reported that STEM education contributes to the development of life skills in the skills feature. It also contributes to the development of problem-solving, intellectual, science process skills, critical thinking skills, engineering design, inquiry, and $21^{\text {st }}$ century skills of students.

Further, this study's findings supported the positive impact of STEM education on reasoning skills. The first result for the first research question has shown a statistically significant

\begin{tabular}{|c|c|c|}
\hline Scheme tested & Question pair & Task details \\
\hline $\begin{array}{l}\text { Conservation } \\
\text { Laws } \\
\text { (conservation } \\
\text { of weight; } \\
\text { conservation of } \\
\text { volume) }\end{array}$ & $\begin{array}{l}1-2 ; 3-4 \\
(2 \text { numbers of two-tier } \\
\text { multiple choice) }\end{array}$ & $\begin{array}{l}\text { Varying the shapes of two } \\
\text { indistinguishable balls of } \\
\text { clay put on opposite ends } \\
\text { of a balance; examining the } \\
\text { displacement volumes of two } \\
\text { cylinders of different densities }\end{array}$ \\
\hline $\begin{array}{l}\text { Proportional } \\
\text { reasoning }\end{array}$ & $\begin{array}{l}5-6 ; 7-8 \\
(2 \text { numbers of two-tier } \\
\text { multiple choice) }\end{array}$ & $\begin{array}{l}\text { Pouring water between wide } \\
\text { and narrow cylinders and } \\
\text { predicting scales }\end{array}$ \\
\hline $\mathrm{CV}$ & $\begin{array}{l}9-10 ; 11-12 ; 13-14 \\
(3 \text { numbers of two-tier } \\
\text { multiple choice) }\end{array}$ & $\begin{array}{l}\text { Designing experiments to test } \\
\text { the influence of the length } \\
\text { of string on the period of a } \\
\text { pendulum; Using fruit flies in } \\
\text { tubes to examine the influence } \\
\text { of red/blue light and gravity } \\
\text { on flies' responses }\end{array}$ \\
\hline $\begin{array}{l}\text { Probabilistic } \\
\text { reasoning }\end{array}$ & $\begin{array}{l}15-16 ; 17-18 \\
(2 \text { numbers of two-tier } \\
\text { multiple choice) }\end{array}$ & $\begin{array}{l}\text { Predicting chances for } \\
\text { withdrawing certain colored } \\
\text { wooden blocks from a sack }\end{array}$ \\
\hline $\begin{array}{l}\text { Correlation } \\
\text { reasoning }\end{array}$ & $\begin{array}{l}19-20 \\
(1 \text { number of two-tier } \\
\text { multiple choice })\end{array}$ & $\begin{array}{l}\text { Predicting whether a } \\
\text { correlation exists between } \\
\text { the size of the mice and the } \\
\text { color or their tails through } \\
\text { presented data }\end{array}$ \\
\hline HDR & $\begin{array}{l}21-22 ; 23 ; 24 \\
(1 \text { number of two-tier } \\
\text { multiple choice and } \\
2 \text { numbers of general } \\
\text { multiple questions }\end{array}$ & $\begin{array}{l}\text { Designing experiments to } \\
\text { determine why the water } \\
\text { rushed up into the glass after } \\
\text { the lighted candle went out; } \\
\text { designing experiments to } \\
\text { determine why red blood } \\
\text { cells become smaller after } \\
\text { the addition of a few drops of } \\
\text { saltwater }\end{array}$ \\
\hline
\end{tabular}

LCTSR: Lawson's classroom test of scientific reasoning, CV: Control of Variables HDR: Hypothetical-deductive Reasoning

\begin{tabular}{|c|c|c|c|}
\hline \multicolumn{4}{|c|}{ Response pattern and score assignment } \\
\hline "00" & "01" & "10" & "11" \\
\hline 0 & 0 & 1 & 2 \\
\hline
\end{tabular}

$\begin{aligned} & \text { Table 5: Descriptive statistics for students' reasoning } \\
& \text { skills test in both groups }\end{aligned}$
\begin{tabular}{lcccc}
\hline Group & N & M & SD & Std. Error Mean \\
\hline $\begin{array}{l}\text { Pre-test } \\
\text { Traditional }\end{array}$ & 27 & 4.4074 & 2.30817 & 0.44421 \\
STEM & 31 & 3.3871 & 1.80143 & 0.32355 \\
Post-test & & & & \\
$\quad$ Traditional & 29 & 2.7931 & 1.80038 & 0.33432 \\
STEM & 29 & 4.4483 & 1.45372 & 0.26995 \\
\hline
\end{tabular}

difference between students' reasoning skills in the traditional group and STEM group. STEM instruction emerges as an effective instruction in strengthening students' reasoning skills, especially for secondary level. The contribution of the current 
5. To the right are drawings of a wide and a narrow cylinder. The cylinders have equally spaced marks on them. Water is poured into the wide cylinder up to the 4th mark (A). This water rises to the 6th mark when poured into the narrow cylinder (B).

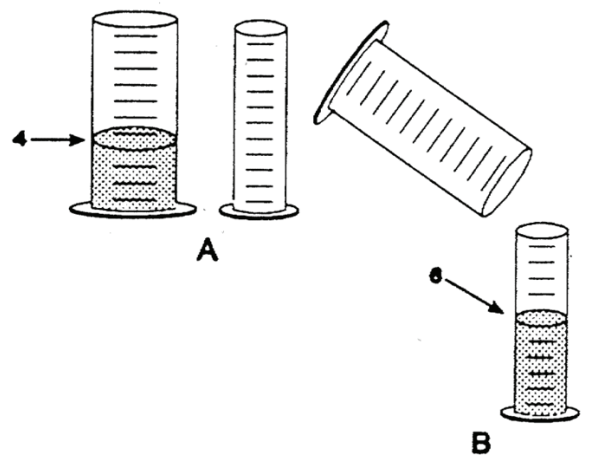

Both cylinders are emptied (not shown), and water is poured into the wide cylinder up to the 6th mark. How high would this water rise if it were poured into the empty narrow cylinder?
a. to about 8
b. to about 9
c. to about 10
d. to about 12
e. none of these answers is correct

6. because
a. The answer cannot be determined with the information given.
b. It went up 2 more before, so it will go up 2 more again.
c. It goes up 3 in the narrow for every 2 in the wide.
d. The second cylinder is narrower.

Figure 2: Example of Lawson's classroom test of scientific reasoning two-tier item questions in probabilistic reasoning skill

Table 6. Analysis covariance result.

\begin{tabular}{|c|c|c|c|c|c|c|}
\hline Source & Type III Sum of Squares & df & Mean Square & $\mathbf{F}$ & $\rho$ & Partial Eta Squared \\
\hline Corrected model & $42.594^{\mathrm{a}}$ & 2 & 21.297 & 7.703 & 0.001 & 0.225 \\
\hline Intercept & 123.776 & 1 & 123.776 & 44.770 & 0.000 & 0.458 \\
\hline Pre-test & 1.827 & 1 & 1.827 & 0.661 & 0.420 & 0.012 \\
\hline Group & 42.585 & 1 & 42.585 & 15.403 & 0.000 & 0.225 \\
\hline Error & 146.531 & 53 & 2.765 & & & \\
\hline Total & 925.000 & 56 & & & & \\
\hline Corrected total & 189.125 & 55 & & & & \\
\hline
\end{tabular}

a. R squared $=0.225$ (Adjusted $\mathrm{R}$ squared $=0.196$ )

study lies in highlighting STEM instruction that can contribute to strengthening reasoning skills, which are crucial in developing countries including Indonesia. Some researchers argue that it can be caused by embedded elements in STEM instruction such as hand-on activity, mind-on activity, and communication of findings that could enhance the students' science skills. This indicates that STEM instruction is influential in understanding science concept (Angwal et al., 2019; Hiong and Osman, 2015; Sari et al., 2017).
In this study, STEM instruction provided experiences to students on how the science concept of hydraulic system could be developed through the engineering design, how the principles of the hydraulic system was utilized in industrial application for daily life uses. STEM instruction also provided sharing sessions about the design process, the students' hypothesis and their solution. These STEM processes become part of the data collection and become the important element in this study. 


\begin{tabular}{lcccc}
\hline $\begin{array}{l}\text { Table 7: Paired sample t-test between pre- and post-test } \\
\text { scores of the traditional group }\end{array}$ & & & \\
\hline Reasoning skills & $\begin{array}{c}\text { M } \\
\text { (pre-test) }\end{array}$ & $\begin{array}{c}\text { M } \\
\text { (post-test) }\end{array}$ & $\mathbf{t}$ & $\rho$ \\
& 0.7037 & 0.6296 & 0.485 & 0.631 \\
$\begin{array}{l}\text { Conservation weight } \\
\text { and volume }\end{array}$ & & & \\
Proportional reasoning & 0.0370 & 0.0000 & 1.441 & 0.161 \\
CV & 0.4074 & 0.1111 & 3.024 & 0.006 \\
Probabilistic reasoning & 0.0556 & 0.3519 & -3.049 & 0.005 \\
Correlation & 0.4074 & 0.1481 & 1.892 & 0.070 \\
HDR & 0.3951 & 0.0988 & 3.889 & 0.001 \\
\hline
\end{tabular}

\begin{tabular}{lcccc}
\hline $\begin{array}{l}\text { Table 8: Paired sample t-test between pre- and post-test } \\
\text { scores of stem group }\end{array}$ & & & & \\
\hline Reasoning skills & $\begin{array}{c}\text { M } \\
\text { (Pre-test) }\end{array}$ & $\begin{array}{c}\text { M } \\
\text { (Post-test) }\end{array}$ & $\mathbf{t}$ & $\rho$ \\
\hline $\begin{array}{l}\text { Conservation weight and } \\
\text { volume }\end{array}$ & 0.6897 & 0.7586 & -0.472 & 0.641 \\
Proportional reasoning & 0.0690 & 0.1034 & -528 & 0.602 \\
CV & 0.1494 & 0.1725 & -0.465 & 0.646 \\
Probabilistic reasoning & 0.3621 & 0.3448 & 0.157 & 0.876 \\
Correlation & 0.5862 & 0.4138 & 1.095 & 0.283 \\
HDR & 0.0690 & 0.3678 & -6.666 & 0.000 \\
\hline
\end{tabular}

In addition, further analysis was conducted to answer the second research question. Students appeared to be losing abilities when they were traditionally taught and this study found the significant differences in probabilistic reasoning skills. This researcher believes that the students' attention during the post-test is one of the factors of this result.

Meanwhile, STEM group might be improving in lout of the six reasoning skills. It revealed the mean score improvement of four subskills (conservation of weight and volume, proportional reasoning, $\mathrm{CV}$, and HDR). However, only HDR skills produced a significant difference. This researcher argues that this result may be caused by the STEM learning process in this study as it focused more on the reasoning process. Students had three meetings in designing experiment and they were trained to provide the possible/correct explanation/solution to build hydraulic robot. These learning processes may have lead the students to a stronger HDR skill.

There were many more challenges that should be solved to strengthen the whole domain in reasoning skills through STEM instruction. This researcher believes that strengthening reasoning skills through STEM is not as simple as conducting classes with STEM learning. Based on the previous research, there should be six foundations as a guide toward performing STEM instruction in class, as was done in this study. First, the integration of the four disciplines (STEM) should influence students to engage in learning to be personally meaningful. Second, STEM should encourage exploring the technology to contribute to the engineering perspective and designing in solving real-world problems. Third, STEM should allow students to implement engineering design from the beginning, failure, and participate in remodeling to teach engineering thinking skills. Fourth, STEM should happen in the standard science and mathematics curriculum. Finally, foundation in STEM should be taught in a student-centered manner and emphasize communication and collaboration skills (Moore et al., 2014). These points can support the effort in strengthening reasoning skills and can be achieved through such class management that identifies with collaborative learning (Marusic and Slisko, 2012).

\section{CONCLUSIONS}

This study aimed to determine the effects of STEM instruction on secondary school students' reasoning skills. Based on the result of this study, STEM instruction emerged as an effective instruction in strengthening students' reasoning skills, especially for secondary level. STEM group showed the mean improvement in conservation weight and volume skill, proportional reasoning skill, CV skill, and HDR. Meanwhile, traditional group showed the mean improvement only in probabilistic reasoning skill.

\section{RECOMMENDATIONS}

This researcher offers the following recommendations that should be done in future research. The first limitation in this was a time limitation. Meanwhile, it is believed that the effect of STEM instruction on reasoning skills can be observed after a longer period of time. The students need time to adjust to the new system and to process information. Thus, it is recommended that future studies include a longer time period of the measurement. Thus, the future research would show more significant results on the relationship between STEM instruction and reasoning skills.

Moreover, the second limitation was the limited experience of the teacher in utilizing STEM instruction. Hence, it is recommended that teachers have sufficient knowledge and skills about STEM instruction and reasoning skills so that they are able to implement and utilize mathematical and scientific concepts in STEM classes. In the STEM instruction, teachers are the "most knowledgeable other" or "master thinker" in the classroom context. Teachers are the model for questioning, wondering, and curiosity; brainstorming processes; developing the plan; generating a litany of educated guesses about a particular situation; and examining theories, ideas, and potential solutions espoused by others (Blue, 2014). Teachers and also education support staff should also make every effort to support the learning process, so students can expand their way of thinking to develop their ability in science.

\section{REFERENCES}

Akaygun, S., \& Aslan-Tukak, F. (2016). STEM images revealing STEM conceptions of preservice chemistry and mathematics teachers. International Journal of Education in Mathematics Science and Technology, 4(1), 56-71.

Akerson, V.L., Burgess, A., Gerber, A., Guo, M., Khan, T.A., \& Newman, S. 
(2018). Disentangling the meaning of STEM: Implications for science education and science teacher education. Journal of Science Teacher Education, 29(1), 1-8.

Alshamali, M.A., \& Daher, W.M. (2016). Scientific reasoning and its relationship with problem solving: The case of upper primary science teacher. International Journal of Science and Mathematics Education, 14(6), 1003-1019.

Altan, E.B., Ozturk, N., \& Turkoglu, A.Y. (2018). Socio-scientific issues as a context for STEM education: A case study research with pre-service science teachers. European Journal of Educational Reseach, 7(4), 805-812.

Andersen, C., \& Garcia-Mila, M. (2017). Scientific reasoning during inquiry. In: Taber, K.S., \& Akpan, B., (Eds.), Science Education. New Directions in Mathematics and Science Education. Rotterdam: Sense Publishers. pp. 105-118.

Angwal, Y.A., Saat, R.M., \& Sathasivam, R.V. (2019). Preparation and validation of an integrated STEM instructional material for genetic instruction among year 11 science students. Malaysian Online Journal of Educational Sciences, 7(2), 41-56.

Asunda, P.A. (2014). A conceptual framework for STEM integration into curriculum through career and technical. Journal of STEM Teacher Education, 49(1), 3-15.

Blue, E.V. (2014). In: Green, S.L. (Ed.), Effective STEM Instruction in K-12 Setting. Hauppauge: Nova Science Publisher.

Burghardt, M.D., \& Hacker, M. (2004). Informed design: A contemporary approach to design pedagogy as the core process in technology. The Technology Teacher, 64(1), 6-8.

Cevik, M., \& Ozgunay, E. (2018). STEM education through the perspectives of secondary schools teachers and school administrators in Turkey. Asian Journal of Education and Training, 4(2), 91-101.

Chiu, A., Price, C.A., \& Ovrahim, E. (2015). Supporting Elementary and Middle School STEM Education at the Whole-School Level: A Review of the Literature. Chicago, IL: Paper Presented at the NARST 2015 Annual Conference.

DeCoito, I., Steele, A., \& Goodnough, K. (2016). Introduction to the special issue on science, technology, engineering, and mathematics (STEM) education. Canadian Journal of Science Mathematics and Technology Education, 16(2), 109-113.

Ding, L., Wei, X., \& Lui, X. (2016). Variations in university students' scientific reasoning skills across majors, years, and types of institutions. Research in Science Education, 46(5), 613-632.

English, L.D. (2016). STEM education K-12: Perspectives on integration. International Journal of STEM Education, 3(3), 1-8.

Fransisca, N., Sisdiana, E., Dian, N., \& Arie, B. (2019). Adapting STEM Education [Mengadaptasi Pembelajaran STEM]. Helsinki: Ministry of Education and Cultural.

Gentles, S.J., Charles, C., Ploeg, J., \& McKibbon, K. (2015). Sampling in qualitative research: Insights from an overview of the methods literature. The Qualitative Report, 20(11), 1772-1789.

Gormally, C., Brickman, P., \& Lutz, M. (2012). Developing a test of scientific literacy skills (TOSLS): Measuring undergraduates' evaluation of scientific information and arguments. CBE-Life Sciences Education, 11, 364-377.

Hiong, L.C., \& Osman, K. (2015). An interdisciplinary approach for biology, technology, engineering and mathematics (BTEM) to enhance $21^{\text {st }}$ Century skills in Malaysia. K-12 STEM Education, 1(3), 137-147.

Huri, N.H.D., \& Karpudewan, M. (2019). Evaluating the effectiveness of integrated STEM-Lab activities in improving secondary school students' understanding of electrolysis. Chemistry Education Research and Practice, 20, 495-508.

Jacobs, J.E., \& Eccles, J.S. (2000). Parents, Task Values, and Real Life Achievement Related Choices. Cambridge: Academic Press.

Jang, H. (2016). Identifying $21^{\text {st }}$ Century STEM competencies using workplace data. Journal of Science Education and Technology, 25, 284-301.

Kanadli, S. (2019). A meta-summary of qualitative findings about STEM education. International Journal of Instruction, 12(1), 959-976.

Kelley, T.R., \& Knowles, J.G. (2016). A conceptual framework for integrated STEM education. International Journal of STEM Education, 3(11), 1-11.

Kuhn, D., \& Dean, D.J. (2004). Connecting scientific reasoning and causal inference. Journal of Cognition and Development, 5(2), 261-288.

Kuhn, D., Schauble, L., \& Garcia-Mila, M. (1992). Cross-domain development of scientific reasoning. Cognition and Instruction, 9(4),
285-327.

Lawson, A.E. (1978). The development and validation of a classroom test of formal reasoning. Journal of Research in Science Teaching, 15(1), 11-24.

Lawson, A.E. (2000). Classroom Test of Scientific Reasoning. Arizona: Arizona State University.

Lawson, A.E., Banks, D.L., \& Logvin, M. (2007). Self-efficacy, reasoning ability, and achievement in college biology. Journal of Research in Science Teaching, 44(5), 706-724

Lee, C.Q., \& She, H.C. (2010). Facilitating students' conceptual change and scientific reasoning involving the unit of combustion. Research in Science Education, 40, 479-504.

Marusic, M., \& Slisko, J. (2012). Influence of three different methods of teaching physics on the gain in students' development of reasoning. International Journal of Science Education, 34(2), 301-326.

Means, B., Wang, H., Wei, X., Lynch, S., Peters, V., Young, V., \& Allen, C. (2017). Expanding STEM opportunities through inclusive STEMfocused high schools. Science Education, 101, 681-715.

Meyrick, K.M. (2011). How STEM education improves student learning. Meridian K-12 School Computer Technologies Journal, 14(1), 1-5.

MoEC. (2016). Peraturan Menteri Pendidikan dan Kebudayaan Republik Indonesia Nomor 20 Tahun 2016 Tentang Standar Kompetensi Lulusan Pendidikan Dasar dan Menengah [Act Ministry of Education and Culture No. 20 of 2016 About Competency Standard for Elementary and Secondary Education]. Available from: https://www.bsnpindonesia.org/wp-content/uploads/2009/06/permendikbud_tahun2016 nomor021_lampiran.pdf.

Moore, T.J., Glancy, A.W., Tank, K.M., Kersten, J.A., \& Smith, K.A. (2014) A framework for quality K-12 engineering education: Research and development. Journal of Pre-College Engineering Education Research, $4(1), 1-13$

Moore, T.J., Stohlmann, M.S., Wang, H.H., Tank, K.M., Glancy, A.W., \& Roehrig, G.H. (2014). Implementation and integration of engineering in K-12 STEM education. In: Purzer, Ș., Strobel, J., \& Cardella, M.E., (Eds.), Engineering in Pre-College Settings: Synthesizing Research, Policy, and Practices. West Lafayette: Purdue University Press. pp. 35-60.

National Research Council. (2011). A Framework for K-12 Science Education: Practices, Crosscutting Concepts, and Core Ideas. Washington, DC: National Reseach Council, Board on Science Education, Division of Behavioral and Social Science and Education.

National Research Council. (2014). STEM Integration in K-12 Education: Status, Prospects, and an Agenda for Research. Washington, DC: The National Academies Press.

National Sciecne Teacher Assocation. (2004). NSTA Position Statement: Transitioning from Scientific Inquiry to Three-Dimensional Teaching and Learning. Available from: https://www.nsta.org/about/positions/3d.aspx.

Opitz, A., Heene, M., \& Fischer, F. (2017). Measuring scientific reasoning-a review of test instruments. Educational Research and Evaluation, 23(34), 78-101.

Osborne, J. (2013). The $21^{\text {st }}$ Century challenge for science education: Assessing scientific reasoning. Thinking Skills and Creativity, 10, 265-279.

Pedaste, M., Maeots, M., Siiman, L.A., Jong, T.D., Riesen, S.A.N., Kamp, E.T., Manoli, C.C., Zacharia, Z.C., \& Tsourlidaki, E. (2015) Phases of inquiry-based learning: Definitions and the inquiry cycle. Educational Research Review, 14, 47-61.

Piaget, J. (1969). The Psychology of the Child. New York: Basic Books.

Preus, B. (2012). Authentic instruction for $21^{\text {st }}$ Century learning: Higher order thinking in an inclusive school. American Secondary Education, 40(3), 59-79.

Radloff, J., \& Guzey, S. (2016). Investigating preservice STEm teacher conceptions of STEM education. Journal of Science Education and Technology, 25(5), 759-774.

Sallee, C.W., Edgar, D.W., \& Johnson, D.M. (2013). Student perceptions of instructional methods towards alternative energy education. Journal of Agricultural Education, 54(2), 130-142.

Sanders, M. (2009). STEM, STEM education, STEMmania. Technology Teacher, 68(4), 20-26.

Sari, U., Alici, M., \& Sen, O.F. (2017). The effect of STEM instruction on attitude, career perception and career interest in a problem-based learning environment and student opinions. Electronic Journal of Science Education, 22(1), 1-21. 
Schnittka, C. (2017). STEM road map: A framework for integrated STEM education. The Journal of Educational Research, 110(3), 317-317.

Shernoff, D.J., Sinha, S., Bressler, D.M., \& Ginsburg, L. (2017). Assessing teacher education and professional development needs for the implementation of integrated approaches to STEM education. International Journal of STEM Education, 13(4), 1-16.

Stammen, A.N., Malone, K.L., \& Irving, K.E. (2018). Effects of modelling instruction professional development on biology teachers' scientific reasoning skills. Education Research, 8(3), 1-19.

Suhandi, M.A., \& Nugraha, M.G. (2017). Development of Reasoning Test Instruments Based on TIMSS Framework for Measuring Reasoning Ability of Senior High School Student on the Physics Concept. Bandung, Indonesia: Paper Presented at the International Seminar on Mathematics, Science, and Computer Science Education.

Sundre, D.L., \& Thelk, A.D. (2010). Advancing assessment of quantitative and scientific reasoning. Numeracy, 3(2), 619-634.

The World Bank. (2019). Program Information Document: Indonesia
Skills Development Project. Available from: http://www.documents. worldbank.org/curated/en/594741563369992590/pdf/concept-stageprogram-information-document-pid-indonesia-skills-developmentproject-p166693.pdf.

Tsupros, N., Kohler, R., \& Hallinen, J. (2009). STEM Education: A Project to Identify the Missing Components. Pittsburgh: Intermediate Unit 1 and Carnegie Mellon University.

Vygotsky, L.S. (1978). Mind in Society: The Development of Higher Psychological Processes. Cambridge: Harvard University Press.

Warner, A.J., \& Myers, B.E. (2012). What is Inquiry-Based Instruction. Available from: http://www.edis.ifas.ufl.edu/wc075.

Wasserman, N.H., \& Rossi, D. (2015). Mathematics and science teachers' use of and confidence in empirical reasoning: Implications for STEM teacher preparation. School Science and Mathematics, 115(1), 22-34.

Zimmerman, C. (2005). The Development of Scientific Reasoning Skills: What Psychologists Contribute to an Understanding of Elementary Science Learning. United States: Illinois State University. 